\title{
A DialÉTicA E a MALANDRAgEM
}

\section{Dialectics and malandragem}

\author{
André Bueno
}

Ao analisar os pressupostos do ensaio Dialética da malandragem, de Antonio Candido, e sem esquecer a ressalva do "salvo engano" que está no título ${ }^{1}$, Roberto Schwarz apresenta, ao mesmo tempo, um elogio daquele que seria o primeiro ensaio dialético da crítica brasileira, e uma discordância de fundo, que diz respeito justamente à oscilação entre ordem e desordem no Brasil, trazendo à tona o lado negativo dessa oscilação. Pode-se dizer, antecipando um pouco a elaboração do argumento, que Roberto Schwarz discorda da visão cultural otimista do país e da sociabilidade popular, presente no ensaio de Antonio Candido em sua parte final, ao contrário de toda a primeira parte, que monta figuras de outra ordem e próximas do marxismo, embora não utilize sua terminologia. A Dialética da malandragem é de $1970^{2}$, e Schwarz usa como referência negativa da oscilação entre ordem e desordem no Brasil justo a ditadura militar, começada em 1964 e aguçada depois de 1968. Vista desse ângulo, a referida oscilação muda de figura e se apresenta como um problema dos maiores, sem ponto de apoio possível numa visão otimista, simpática aos de baixo e de base cultural, que se resolveria numa espécie de suspensão do mal-estar na civilização periférica nos trópicos, em termos de sociabilidade popular folgada, do país ainda em formação à época das Memórias de um sargento de milícias, que culminaria no Modernismo paulista, em Macunaima e Serafim Ponte-Grande.

Seguida essa linha de análise, a visão otimista e positiva da oscilação entre ordem e desordem, traduzida numa sociabilidade mais folgada e menos rigorosamente definida pela ética do capitalismo e suas normas exigentes, poderia significar uma futura inserção do Brasil numa ordem mundial mudada, diferente do capitalismo e seu modo de moldar a vida, os instintos e os impulsos, deformando a expressão natural dos instintos humanos em termos de culpa, pecado, norma, intolerância e superego

${ }^{1}$ SCHWARZ, Roberto. Pressupostos, salvo engano, de Dialética da malandragem. In: Que horas são? São Paulo: Cia das Letras, 1987. p. 129.

${ }^{2}$ CANDIDO, Antonio. Dialética da malandragem. Revista do Instituto de Estudos Brasileiros da USP, n. 8, 1970. 
duramente introjetado. Talvez se possa dizer, sem forçar a mão, que a primeira parte da Dialética da malandragem, que é próxima do marxismo e com a qual Roberto Schwarz concorda, dá lugar, na parte final, a uma posição que faz mesmo lembrar Freud, lido por um ângulo positivo, indicando, no Brasil em formação, a partir da vida dos de baixo, um superego mais maleável, imune à intolerância, portanto até certo ponto livre da expressão necessária do mal-estar na civilização. Algo diferente do puritanismo norte-americano, o que nos tornaria mais protegidos contra a intolerância e as caças às bruxas, que resultariam dos grupos sociais muito fechados, com normas bem definidas para definir o certo e o errado, a ordem e a desordem, a norma e a infração da norma. Também não é difícil notar que essa visão otimista e simpática de Antonio Candido é tributária do Modernismo paulista, à frente Mário de Andrade e Oswald de Andrade, assim como do ensaísmo brasileiro dos anos de 1930, sobretudo Sérgio Buarque de Hollanda e Gilberto Freyre. Como se verá mais adiante, Roberto Schwarz nota que esse tipo de otimismo sofreu a crítica impiedosa da atualidade, já que a formação do próprio capitalismo, em nosso país e no mundo, tomou um rumo diferente, com certeza negativo e sem lugar para o otimismo de fundo cultural.

Antes de continuar analisando o problema crítico, vale a pena retomar alguns pontos de referência para o debate. O primeiro está na própria Formação da literatura brasileira- momentos decisivos, de Antonio Candido, que é da década de $1950^{3}$. Naquela altura, o crítico analisa as Memórias de um sargento de milícias, de Manuel Antônio de Almeida, como romance em moto-contínuo. Considera o livro, de resto simples e sem grandes pretensões, como excêntrico, uma "preflorescência do Realismo", cujo ponto de maturidade certamente seria Machado de Assis. Antonio Candido ressalta a imparcialidade no tratamento dos personagens, indo além da crua oposição entre o Bem e o Mal, típica dos românticos. Mais que isso, ainda considera as Memórias um romance picaresco, posição que iria mudar na Dialética da malandragem, em que é refutada justamente a filiação picaresca, situando o livro de Manuel Antonio como romance malandro, bastante representativo de uma relação forte entre literatura e sociedade no país em formação à época. O crítico também nota que o espaço das Memórias é concentrado, por contraste com a picaresca espanhola e o romance inglês.

Quanto aos personagens, Antonio Candido percebe uma bizarrae alegre sarabanda, num romance de costumes em que tudo existe para a ação, fazendo com que os acontecimentos só importem para acentuar personagens singulares. Nas Memórias, os personagens mudam o tempo todo de posição na sarabanda dos costumes, açôes e eventos. Os personagens seguem à risca o romance de costumes, cujas normas e tipos Manuel Antonio segue à risca, passando ao largo do que pudesse ser excepcional ou patético, ao modo romântico mais conhecido. Assim sendo, os personagens são

${ }^{3}$ CANDIDO, Antonio. O romance em moto-contínuo. In: Formação da literatura brasileira - momentos decisivos. 10. ed. rev. pelo autor. Rio de Janeiro: Ouro sobre Azul, 2006. p. 531. 
definidos pela profissão, pela função, e não pelo nome. Nos termos de E. M. Forster, ponto de apoio de Antonio Candido nesse passo da análise, seriam flat characters - simples pinceladas, iguais a si mesmos, não mudam. Portanto, seriam personagens sem psicologia, tudo unido por usos, costumes e episódios. Quanto à composição, as Memórias seguiriam o movimento mais amplo do panorama social, fazendo com que o tempo se apresente como unidade fluida e precária, em que "o movimento e a agitação incessante do livro pressupóem o tempo, mas não se inserem devidamente nele" 4 . No fecho da análise, Antonio Candido resume: "Manuel Antonio de Almeida é, por excelência, em nossa literatura romântica, o romancista de costumes", e seu livro "o mais rico em informaçóes seguras, o que mais objetivamente se embebe numa dada realidade social" 5 .

Como se há de notar, em nenhum momento Antonio Candido, na análise que apresenta na Formação da literatura brasileira - momentos decisivos, considera as Memórias de um sargento de milícias um romance malandro. Nem estabelece uma linhagem, da qual o livro faria parte, como se lerá depois, na Dialética da malandragem, indicando Pedro Malasarte e Gregório de Matos como antecessores, tendo como sucessores, e culminância, Macunaima e Serafim Ponte-Grande, no Modernismo paulista dos anos de 1920. Cabe acrescentar que em $O$ romance em moto-continuo as desvantagens do Brasil aparecem apenas como desvantagens, em termos da dinâmica frouxa do país frágil, disperso, pouco organizado, com uma formação irregular. São apenas desvantagens objetivas, que o livro excêntrico do jovem Manuel Antonio apresenta em termos de moto-contínuo, de suspensão do juízo moral, de alegre sarabanda, que não é narrada pelo ângulo da classe dominante. Cabe notar aqui essa figura da música, a sarabanda, que na Dialética da malandragem Antonio Candido leva adiante, aproximando as Memórias da ópera bufa, do mundo onde tudo é burla, mas também é sério, culminando no allegro vivace de um mundo sem culpa, suspenso que estaria o superego, individual e social, aliviando o mal-estar na civilização periférica e tropical. Dado esse passo, é certo que as desvantagens do país vão se apresentar como vantagens, fazendo com que traços culturais populares, e modos populares de vida, apareçam como diferenças positivas, sempre por contraste com o puritanismo norteamericano.

O segundo ponto de referência para o debate é o artigo No tempo do rei, de Walnice Nogueira Galvão, primeiro publicado em 1962, no jornal O Estado de S. Paulo, depois em 1976, no livro Saco de gatos - ensaios críticos $^{6}$. Ensaio que Antonio Candido refere, de modo elogioso, em nota de pé-de-página da Dialética da malandragem. Também por contraste com

${ }^{4}$ Idem.

${ }^{5}$ Idem.

${ }^{6}$ GALVÃo, Walnice Nogueira. No tempo do rei. In: Saco de gatos - ensaios críticos. São Paulo: Livraria Duas Cidades, 1976. p. 27. 
Machado de Assis, ponto alto e maduro do realismo no Brasil, Walnice Nogueira Galvão percebe Manuel Antônio de Almeida como antes de tudo um cronista, uma espécie de mestre-de-cerimônias onisciente, que mantêm diante da matéria narrada uma distância jocosa, que não transcende o imediato. A autora também nota, no que diz respeito à composição das Memórias, que na primeira parte "o quadro ambiental predomina sobre $o$ enredo", levando na direção dos costumes da época, mas na segunda parte "o enredo toma conta, passando o pitoresco [...] para o segundo plano". Observação que faz lembrar a distinção desenvolvida por Antonio Candido, na Dialética da malandragem, entre romance documental e romance representativo, mostrando que a força do livro está justamente na distância que toma dos traços pitorescos e folclóricos do Rio de Janeiro da época joanina.

Quanto ao tempo, Walnice Nogueira Galvão percebe que é trabalhado "dentro de cada episódio em si mesmo", e que "o ritmo se altera muito, em certos episódios se precipita e adquire grande vivacidade" ". Quanto aos personagens, seriam planos em estilo baixo, com uma tendência ao grotesco, recusando qualquer pathos e fazendo uso da linguagem corrente. A nota comparativa do ensaio de Walnice Nogueira Galvão se lê na aproximação das Memórias com o Tom Jones, de Fielding, no qual destaca um personagem todo íntegro, Allsworthy. Quanto ao ponto de vista, o real seria por inteiro externo ao livro de Manuel Antonio de Almeida, como mero objeto, não havendo continuidade alguma entre o externo e o interno. Ou seja, como se não houvesse nas Memórias material para uma dialética forte entre literatura e sociedade, forma literária e processo social, marcando aqui uma diferença importante, tanto em relação a Antonio Candido quanto a Roberto Schwarz.

O mais importante de "No tempo do rei" talvez esteja mesmo no problema do caráter nacional brasileiro e suas variações. Leonardo não é definido diretamente como malandro, mas as características do personagem apontam nessa direção, já que tem verve, desapego às convenções, espírito aventureiro, travesso, malcriado, vadio-tipo, desenvolto, refinado velhaco, com gosto pelas mulheres 8 . O modo como o major Vidigal escolhe Leonardo para ser sargento, aqui também comparece: "sendo naturalmente astuto $e$ tendo até ali vivido numa rica escola de vadiação e peraltismo, deveria conhecer todas as manhas do oficio" ". Feita a caracterização do personagem Leonardo, a análise encaminha sua crítica para o problema do caráter nacional brasileiro. Primeiro, notando o seguinte: "É desse modo que Manuel Antônio de Almeida caracteriza o personagem Leonardo, que resulta num herói sem nenhum caráter, ou melhor, que apresenta os traços fundamentais

\footnotetext{
${ }^{7}$ Idem .

${ }^{8}$ Ibidem, p. 31.

${ }^{9}$ Ibidem, p. 32.
} 
do estereótipo do brasileiro". Em seguida, que "Manuel Antônio de Almeida é o primeiro a fixar em literatura o caráter nacional brasileiro, tal como terá longa vida em nossas letras". Por fim, a autora afirma: "Creio que se pode saudar em Leonardo o ancestral de Macunaíma" ${ }^{10}$. 0 resumo da análise de Walnice Nogueira Galvão certamente merece atenção, sobretudo em sua crítica do caráter nacional brasileiro e suas três referências fortes: a) Leonardo, herói sem nenhum caráter, apresenta os traços fundamentais do estereótipo do brasileiro; b) As Memórias fixam pela primeira vez o caráter nacional brasileiro, que certamente teve longa vida em nossa literatura; $\mathrm{c}$ ) Leonardo seria o ancestral de Macunaíma. Ligadas assim diretamente à ideologia do caráter nacional brasileiro, as Memórias de um sargento de milícias não teriam uma forma elaborada, que permitisse uma dialética forte entre literatura e sociedade, ao modo da redução estrutural elaborada por Antonio Candido, ou entre forma literária e processo social, no modelo crítico dialético elaborado por Roberto Schwarz para analisar Machado de Assis, vale dizer, o Brasil e seu lugar no mundo capitalista. Fica indicado o problema, que pode ser desenvolvido.

O ensaio Dialética da malandragem foi publicado, pela primeira, no número oito da revista do Instituto de Estudos Brasileiros, da USP, em 1970. Em livro, sairia anos depois, como parte de $O$ discurso e a cidade, em $1993^{11}$. Está na primeira parte do livro junto com mais três ensaios: Degradação do espaço, análise de L'assomoir, de Zola; O mundo-provérbio, análise de I malavoglia, de Giovanni Verga; e De cortiço a cortiço, análise do livro de Aluisio Azevedo. Juntos, os quatro ensaios formam uma lição primorosa de literatura comparada, apresentando variações que giram todas em torno do realismo, de literatura tributária de uma concepção de realismo. Antonio Candido abre Dialética da malandragem fazendo uma revisão da fortuna crítica do livro, já preparando uma refutação dos que situam as Memórias como romance picaresco, baseando sua análise nos seguintes pontos críticos: o próprio pícaro narra suas aventuras, o que não acontece nas Memórias, livro narrado em terceira pessoa, variando os ângulos primário e secundário; apesar da origem comum, o pícaro e Leonardo diferem, porque este não é largado no mundo, sendo logo protegido pelo Compadre, sendo com isso poupado do "choque áspero com a realidade"; Leonardo já nasce "malandro feito", não havendo choque da ingenuidade com a dureza do mundo; o pícaro vive a condição servil, passando de amo em amo, variando a experiência, conhecendo o conjunto da sociedade e aprendendo com a experiência; Leonardo não vive a condição servil; ambos, o pícaro e Leonardo, são amáveis e espontâneos, vivendo ao sabor da sorte, mas Leonardo não aprende com a experiência, o que traz à tona um ponto importante; a

\footnotetext{
${ }^{10}$ Idem .

${ }^{11}$ CANDIDO, Antonio. Dialética da malandragem. In: $O$ discurso e a cidade. São Paulo: Livraria Duas Cidades, 1993. p. 19.
} 
picaresca é sarcástica e áspera, moldada no choque direto com a realidade, enquanto as Memórias são leves e ligeiras, daí a alegre sarabanda e o allegro vivace; o pícaro endurece, reconhece os interesses que estão em jogo, precisa agradar a seus amos, enquanto Leonardo tem sentimentos, vive história de amor, não precisa agradar a um amo; o pícaro seria um "aventureiro desclassificado", internacional, um dos "modelos da ficção realista moderna", descobrindo a sociedade na "variação dos lugares, dos grupos, das classes...", sendo obsceno e fazendo uso farto de palavrões; já as Memórias são livro limpo, discreto, e "a sátira nunca abrange o conjunto da sociedade" ${ }^{12}$. Como se pode notar através do resumo acima apresentado, o pícaro é um personagem mais forte e complexo que o Leonardo das Memórias, moldado que é pelo choque direto e duro com a realidade, não sobrando espaço para movimentos leves e descolados da necessidade, imposta por sua posição subalterna e servil.

Em seguida, Antonio Candido caracteriza as Memórias como um romance malandro, sendo Leonardo

o primeiro grande malandro que entra na novelística brasileira, vindo de uma tradição quase folclórica e correspondendo, mais do que se costuma dizer, a certa atmosfera cômica e popularesca de seu tempo, no Brasil. Malandro que seria elevado à categoria de símbolo por Mário de Andrade em Macunaíma ${ }^{13}$.

Nesse passo da análise, Antonio Candido mostra como as Memórias combinam um plano voluntário - a representação dos costumes e cenas do Rio - e um plano talvez involuntário - de origem folclórica, atemporal e popular, de cunho arquetípico, com personagens aproximados de paradigmas lendários e da indeterminação da fábula. O ponto principal desse passo da análise é que Antonio Candido percebe no realismo corriqueiro e espontâneo das Memórias uma intuição da dinâmica social do Brasil na primeira metade do século XIX. No plano da história da época, o crítico mostra as afinidades das Memórias com a produção cômica e satírica da Regência e primeiros anos do Segundo Reinado - no jornalismo, na poesia, no desenho, no teatro. o que aproxima Manuel Antônio de Martins Pena, estando presente em ambos a mesma "leveza de mão, o mesmo sentido penetrante dos traços típicos, a mesma suspensão do juizo moral" ${ }^{14}$. Mais que isso, Manuel Antonio também é aproximado da caricatura política da época, como em Araújo Porto Alegre, e dos poetas românticos do tipo cômico, obsceno e maluco ${ }^{15}$.

\footnotetext{
${ }^{12}$ Idem .

${ }^{13}$ Ibidem, p. 25.

${ }^{14}$ Ibidem, p. 30.

${ }^{15}$ Idem
} 
Na parte seguinte do ensaio, Antonio Candido refuta a posição que situa as Memórias como um romance documentário, que seria uma reprodução fiel da sociedade da época. Não é assim, porque as Memórias não comunicam uma visão informativa, estando situadas num espaço restrito, já que a ação acontece nas áreas centrais do Rio, onde os personagens circulam, com uma ou duas saídas para o subúrbio. Além disso, não há escravos no livro, exceto as baianas da procissão - tratadas como elemento decorativo - e a menção às crias da casa de Dona Maria. Como personagem, apenas o pardo livre Chico-Juca, "representante da franja de desordeiros $e$ marginais que formavam uma boa parte da sociedade brasileira" ${ }^{16}$. Ou seja, um documentário na verdade bem restrito: estão ausentes o trabalho e o mando, os escravos e a elite. Os personagens são uma espécie de camada média, de pobres e remediados. Nos termos que se verá mais adiante, na análise de Roberto Schwarz, de homens livres na ordem escravocrata, nem proprietários e nem escravos, sem acesso a um mercado formal de trabalho assalariado, por esse motivo dependentes da proteção e do favor de algum proprietário.

Passo a passo, Antonio Candido vai refutando a interpretação das Memórias como romance documental, ligado ao pitoresco, marcando portanto a diferença entre descrever e narrar e fazendo lembrar Georg Lukács: a narrativa ganha força quando o documento não existe em si, mas é parte da ação, "de maneira que nunca pareça que o autor esteja informando ou desviando nossa atenção para um traço da sociedade" ${ }^{17}$, e os dados só interessam como elemento de composição. Comparando a primeira e a segunda partes das Memórias, Antonio Candido mostra como o romance, emergindo da poeira anedótica, vai se consolidando como romance, daí que a primeira parte tenha cara de crônica e a segunda é mais romance. Mas, seguindo o movimento dialético, a segunda parte preserva o colorido e o pitoresco da vida popular, sem situá-la num excessivo primeiro plano. A conclusão é forte, e interessa bastante: é provável que a impressão de realidade do livro não venha dos informes sobre a vida da época, mas sim de uma visão mais profunda, embora instintiva, da função, ou 'destino', das pessoas nessa sociedade. Continuando a análise, o crítico indica que a singeleza de Manuel Antônio não impede um parentesco com os grandes realistas, a saber: a capacidade de intuir, além dos fragmentos descritos, certos principios constitutivos da sociedade - elemento oculto que age como totalizador dos aspectos parciais ${ }^{18}$.

\footnotetext{
16 Ibidem, p. 32.

${ }^{17}$ Ibidem, p. 34.

${ }^{18}$ Ibidem, p. 35.
} 
Sendo um romance representativo, as Memórias apresentam dois estratos de universalização: a partir dos arquétipos populares, do trickster, do atemporal e também de uma visão do Brasil. Este é o espaço da dialética da ordem e da desordem, "o seu caráter de princípio estrutural, que gera o esqueleto de sustentação, é devido à formalização estética de circunstâncias de caráter social profundamente significativas como modos de existência..." ${ }^{19}$. Temos aí o movimento dialético, o pólo positivo da ordem e negativo da desordem, comunicando-se o tempo todo e situando com isso o sistema de relações dos personagens. Acrescente-se que se trata de ordem e desordem muito relativas, com os personagens se movendo volta e meia entre os dois pólos. Vista desse ângulo, a história de Leonardo Filho é a velha história do herói que passa por diversos riscos até alcançar a felicidade, mas expressa segundo uma constelação social peculiar.

Os passos seguintes da Dialética da malandragem, até sua conclusão otimista, de certo modo abandonam as premissas elaboradas até então, como que saindo da constelação social peculiar, bem situada, e do movimento de totalização que monta as partes, deixando assim de lado uma análise também situada do sistema de personagens e ações das Memórias de um sargento de milícias. A análise toma outro rumo quando o crítico afirma que o cunho especial do livro consistiria numa certa ausência de juizo moral e na aceitação risonha do 'homem como ele é', misturando cinismo e bonomia, mostrando ao leitor a relativa equivalência entre o universo da ordem e da desordem, entre o que se poderia chamar convencionalmente o bem e o mal ${ }^{20}$. Com esse movimento analítico de suspensão da constelação social específica que vinha sendo configurada, o crítico pode afirmar que "tutto nel mondo è burla, parece dizer o narrador das Memórias de um sargento de milícias, romance que tem traços de ópera bufa". No entanto, é burla e é sério, não pelo pitoresco, com certeza, mas por participar do ritmo profundo da sociedade oscilando entre ordem $e$ desordem ${ }^{21}$.

Continuando a análise, Antonio Candido caracteriza o que seria o realismo infuso das Memórias: a tensão entre as duas linhas narrativas,

de um lado o cunho popular introduz elementos arquetipicos, que trazem a presença do que há de mais universal nas culturas, puxando para a lenda e o irreal, sem discernimento da situação histórica particular. De outro lado, a percepção do ritmo social

\footnotetext{
${ }^{19}$ Ibidem, p. 36.

${ }^{20}$ Ibidem, p. 39.

${ }^{21}$ Ibidem, p. 41.
} 
puxa para a representação de uma sociedade concreta, historicamente delimitada, que ancora o livro e intensifica o seu realismo infuso ${ }^{22}$.

Nos termos da crítica de Roberto Schwarz, que se verá mais adiante, ficaria faltando ainda um movimento dialético da análise materialista das Memórias: submeter o material de origem folclórica, popular, arquetípica, à crítica da atualidade, o que mudaria os termos da análise.

Na parte final do ensaio, o mundo sem culpa, Antonio Candido se permite uma adesão entusiasma ao livro de Manuel Antônio, baseada em formas culturais, que merece reflexão. A análise materialista e socialmente situada dá lugar a traços culturais como que suspensos acima do processo social e histórico efetivo, de fato muito difíceis e negativos. Assim sendo, o sistema de ações dos personagens como que se equilibra, na contramão dos romances brasileiros do século XIX, inclusive o cômico, porque "as Memórias de um sargento de milícias criam um universo que parece liberto do peso do erro e do pecado" 23 a isso correspondendo uma visão tolerante, quase amena. O que se tem é um simpático afrouxamento das pressões e exigências da civilização, das suas renúncias e repressões, das necessárias separações entre o lícito e o ilícito, o verdadeiro e o falso, o moral e o imoral, o justo e o injusto, a esquerda ou a direita política. Daí o "ar de facilidade, de visão folgada dos costumes", o que colocaria as Memórias numa tradição forte, a da literatura satírica e do realismo desmistificador, cuja grande função seria justamente mostrar que os pares antitéticos rigorosos que definem as condutas sociais na verdade são reversíveis, "e que fora da racionalização ideológica as antinomias convivem num curioso lusco-fusco".

Definidos os termos da resolução otimista do mal-estar na civilização na sociedade jovem, ainda em formação, o rigor das antinomias e das escolhas como que se tornam apenas mecanismos ideais de contensão, "normas rígidas e impecavelmente formuladas, criando a aparência e a ilusão de uma ordem regular, que não existe..." 24 . Saindo da constelação social particular e situada que vinha construindo, Antonio Candido trata agora da natureza humana, da repressão dos instintos, da força vital desfigurada, que se identifica com os padrões ideais da colonização. Nesse passo da análise, a sugestiva comparação entre Alencar - por exemplo em o guarani, onde tudo é sublimado, tudo é renúncia e repressão, criando um

\footnotetext{
${ }^{22}$ Ibidem, p. 46.

${ }^{23}$ Ibidem, p. 47.

${ }^{24}$ Ibidem, p. 49.
} 
ser alienado e automático - e Oswald de Andrade, no Manifesto Antropófago, com a referência ao "índio tocheiro, indio filho de Maria, afilhado de Catarina de Médicis e genro de D. Antonio de Mariz..." ${ }^{25}$. Esse tipo de "repressão mutiladora da personalidade" se encontraria também nos romances urbanos de Alencar, como Luciola e Senhora, onde "a mulher opressa da sociedade patriarcal confere ao enredo uma penumbra de forças recalcadas" ${ }^{26}$. É como se da luta, do conflito entre Eros e Civilização, entre o princípio de prazer e o princípio de realidade, resultasse na jovem nação escravista um espaço inesperado de folga, de expressão mais solta e menos rigorosa, da natureza humana e seus instintos vitais, o que não deixa de ser uma maneira de tornar vantagem uma desvantagem histórica marcada.

Montada a figura, é possível afirmar que, em meio a tudo, ficaria "a liberdade quase feérica do espaço ficcional de Manuel Antônio, livre de culpabilidade e remorso, de repressão e sançóes interiores, colore e mobiliza o firmamento do Romantismo, como os rojóes do fogo no campo ou as baianas dançando nas procissóes" ${ }^{27}$. A simpatia de Antonio Candido pelos de baixo, pela sociabilidade popular brasileira, por oposição à sincera antipatia pela classe dominante, e pelo capitalismo em geral, permite essa extrapolação. Assim como permite, em seguida, o paralelo entre Brasil e Estados Unidos, através da comparação entre Manuel Antônio e Nathanael Hawthorne, marcando a nítida diferença entre dois tipos de superego social. Antonio Candido usa como exemplo A letra escarlate, para indicar uma sociedade, a norte-americana, desde cedo rigorosa e endurecida, com a presença forte da lei, religiosa e moral, que confere força de identidade e coesão ao indivíduo e ao grupo, mas que também desumaniza a relação com os diferentes, os que não pertencem à mesma lei. Como se lê no seguinte passo da análise:

A alienação torna-se ao mesmo tempo marca de reprovação e castigo do réprobo; o duro modelo bíblico do povo eleito, justificando a brutalidade com os não-eleitos, os outros, reaparece nessas comunidades de leitores quotidianos da Bíblia. Ordem e liberdade - isto é, policiamentos internos e externos, direito de arbítrio e de ação violenta sobre o estranho - são formulações desse estado de coisas $^{28}$.

\footnotetext{
${ }^{25}$ Ibidem, p. 49.

${ }^{26}$ Ibidem, p. 50.

${ }^{27} \mathrm{Idem}$.

${ }^{28} \mathrm{Idem}$.
} 
Por contraste completo com a dureza da análise acima, a de um superego individual e coletivo altamente repressor, Antonio Candido apresenta uma posição que é muito mais que uma análise das modestas Memórias de um sargento de milícias, já que se trata de uma interpretação do Brasil, que deixa de lado todos os pressupostos da primeira parte da Dialética da malandragem:

No Brasil, nunca os grupos ou os individuos encontraram efetivamente tais formas; nunca tiveram a obsessão da ordem senão como principio abstrato, nem da liberdade senão como capricho. As formas espontâneas da sociabilidade atuaram com maior desafogo e por isso abrandaram os choques entre a norma $e$ a conduta, tornando menos dramáticos os conflitos de consciência ${ }^{29}$.

Mais que isso, o Brasil, como sociedade jovem e irregular, "incorpora de fato o pluralismo racial". Em toda a linha, essa posição suspende os conflitos reais da sociedade brasileira, os choques entre as classes, o mando e os desmando das classes dirigentes, a fraqueza das posições subalternas, as diversas e marcadas expressões do racismo à brasileira, a própria dureza da luta pela sobrevivência dos de baixo, quer na sociedade escravista, quer na moderna sociedade urbana de classes.

Mas a simpatia de Antonio Candido, é certo, aponta para outra direção: as Memórias, além do que já foi exposto, interessam porque são uma exceção, um livro que não exprime uma visão de classe dominante. No plano do estilo, se afastando da retórica acadêmica e do estilo beletrista, tomando distância das linguagens fechadas dos grupos restritos e comprometidas com uma certa visão de mundo, entrando aqui como exemplo Iracema, de Alencar. Também nesse passo da análise, se pode notar a posição crítica tributária do Modernismo, da linguagem trazida para o cotidiano, ao mesmo tempo em que se perde vista que essa conquista estilística, inegável, não suspende os conflitos de classe, já que os de cima também podem usar, e usam mesmo, uma linguagem solta, cotidiana, sem deixarem de ser o que são, e agirem como agem, sem traço de culpa.

Seguindo em linha com a simpatia pela sociabilidade popular, com suas formas de humor e de irreverência, de relativa folga na vida cotidiana, Antonio Candido dá mais uma volta no parafuso: "trata-se de uma libertação, que funciona como se a neutralidade moral correspondesse a uma neutralidade social, misturando as pretensóes das ideologias no

${ }^{29}$ Ibidem, p. 51. 
balaio da irreverência popularesca"30. Cá entre nós, é pedir muito, tanto das modestas Memórias de um sargento de milícias, quanto da suposta sociabilidade popular, folgada e malandra. Pode-se dizer que as dimensões fecundas do nosso universo cultural, nesse passo da Dialética da malandragem, ganham um peso excessivo, tendendo a uma idealização culturalista que a realidade não cansa de negar e desmentir. Fechando a análise, Antonio Candido leva longe a oposição cultural entre os valores puritanos das sociedades capitalistas e os valores mais folgados, tolerantes embora corrosivos, como algo muito brasileiro, tendo como ponto de apoio a comicidade que foge às normas da esfera burguesa e que se leria no folclore, em Pedro Malasarte, em Gregório de Matos, em Mário de Andrade e em Oswald de Andrade. O que parecia desvantagem se torna diretamente uma vantagem, a inferioridade do Brasil diante dos países capitalistas avançados se torna algo que facilitará nossa inserção num mundo eventualmente aberto ${ }^{31}$. A limpidez transparente do universo sem culpa das Memórias de um sargento de milícias, a alegre sarabanda, culmina em um allegro vivace. Como se fossem ambos, o livro de Manuel Antônio e o Brasil da sociabilidade popular folgada e tolerante, uma composição musical sem dissonâncias, idealmente suspensa dos atritos e choques com a realidade.

Roberto Schwarz publicou Pressupostos, salvo engano, de Dialética da malandragem em 1979, no volume Esboço de figura homenagem a Antonio Candido, organizado por Celso Lafer $^{32}$. Depois, faria parte do livro Que horas são?, publicado em $1987^{33}$. De modo muito preciso e cuidadoso, os Pressupostos trazem para o debate ao mesmo tempo um elogio daquele que seria o primeiro ensaio dialético da crítica brasileira, mas também uma crítica de fundo, que vale a pena pensar. Pelo lado do elogio, Roberto Schwarz destaca na Dialética da malandragem, desde logo, a distância que o ensaio guarda em relação à ortodoxia marxista e à moda estruturalista da época. Em seguida, os Pressupostos resumem os passos da dialética materialista que se lê na maior parte do ensaio de Antonio Candido. A começar pelos três vértices da análise: a) uma dimensão folclórica e pré-moderna; b) um clima cômico datado - a produção satírica do período regencial; c) e sobretudo uma intuição profunda do movimento da sociedade brasileira. A forma das Memórias, tratadas de modo objetivo, traz à tona sentidos inesperados, a igual distância dos formalistas e dos dogmáticos.

${ }^{30}$ Ibidem, p. 52.

${ }^{31}$ Ibidem, p. 53.

32 SCHWARZ, Roberto. Pressupostos, salvo engano, de Dialética da malandragem. In: LAFER, Celso (Org.). Esboço de figura - homenagem a Antonio Candido. São Paulo: Livraria Duas Cidades, 1979. p. 133. em nota anterior.

${ }^{33}$ As citações a seguir seguem a edição do livro Que horas são?, de 1987, já referida 
Assim sendo, a forma das Memórias suspende o juízo moral e da ótica de classes, oscilando entre ordem e desordem. É essa a redução estrutural: a estilização literária de um movimento profundo da sociedade brasileira, sendo a dialética da ordem e da desordem um princípio de generalização, que organiza os dados da realidade e da ficção, tornando-os inteligíveis e dependendo de princípios mediadores. Ausentes o trabalho e o mando, os proprietários e os escravos, as Memórias se organizam no espaço médio, o dos homens livres na ordem escravocrata. Posição crucial, a desses homens livres dependentes do favor e do arbítrio dos poderosos, não tendo portanto acesso a um mercado formal de trabalho assalariado, vivendo num espaço intermediário e anômico, em que não era possível prescindir da ordem, nem viver dentro dela ${ }^{34}$. Posição que, naquela altura, Roberto Schwarz já havia formulado em Ao vencedor as batatas e que desenvolveria até chegar a Um mestre na periferia do capitalismo - Machado de Assis, anos depois.

Seguindo a lógica do ensaio de Antonio Candido, Roberto Schwarz considera que a dialética da malandragem, em sentido próprio, seria a oscilação entre movimento histórico e arquétipos folclóricos da esperteza popular, o que definiria a tensão interna do ensaio. Sempre ao modo dialético materialista, o crítico considera que o estético e o social não se opõem, fazendo da forma uma síntese profunda do movimento histórico, de modo que a complexidade da forma ajude a pensar e entender a complexidade do real. Em resumo, "leitura estética e globalização histórica são parentes, as duas suspendem o dado num todo complexo, sem suprimi-lo"35. O que se tem é a "imitação de uma estrutura histórica por uma estrutura literária"36. Embora simples, as Memórias são tratadas na Dialética da malandragem como romance realista sério, em que está em jogo o sentido da época, fazendo a passagem da crítica de "edificação nacional", do puramente local, à "crítica estética", que sonda o mundo contemporâneo, ao mesmo tempo fazendo a passagem da crítica que comemora o nacional à crítica que o historiciza. Ou seja, "não o país do coração, mas o verdadeiro, das classes sociais"

Ainda pelo lado do elogio da Dialética da malandragem, Roberto Schwarz enfatiza a elaboração dialética em movimento, o processo de selecionar o que não é evidente, trazendo a análise para a atualidade histórica, localizando o setor da totalidade social cujo movimento a forma do livro sintetiza. Assim procedendo, Antonio Candido reúne conhecimentos e informações dispersos e configura um problema, que até então nem existia, a própria dialética da ordem e da desordem, como princípio mediador que

\footnotetext{
${ }^{34}$ Ibidem, p. 138.

35 Ibidem, p. 135.

${ }^{36}$ Idem .

${ }^{37}$ Ibidem, p. 136.
} 
torna mais ou menos convincente a continuidade entre forma literária e processo social $^{38}$. Assim sendo, a boa análise estética da forma acentua a dimensão cognitiva da ficção, se apresentando como valor de conhecimento da arte, uma espécie de guia efetivo para a descoberta de aspectos inesperados da realidade, não sua mera duplicação ou simples repetição, ao modo de uma tautologia, fácil e previsível.

Nessa altura dos Pressupostos, Roberto Schwarz já começa a encaminhar sua discordância forte com a Dialética da malandragem, e se pergunta por que Antonio Candido não usa a terminologia marxista, indagando se assim o faz para evitar o fetichismo que domina o debate ou, mais importante, se haveria uma discordância de fundo, que não é explicitada. E entra em cena a pergunta crucial: por que interpretar o Brasil a partir desse específico setor da totalidade, dos que não trabalham regularmente, nem mandam e nem acumulam, localizando ai uma longa tradição, a própria dialética da malandragem?

Continuando a apresentação dos Pressupostos, Roberto Schwarz situa um problema de método dialético com muitas consequências: a originalidade não está em ligar literatura e sociedade, o que seria algo comum, mas em explorar a dimensão objetiva da forma e buscar os correlativos na ordem social, escapando tanto do formalismo quanto do sociologismo vulgares, que não configuram o problema nas duas pontas. Na Dialética da malandragem, Roberto Schwarz percebe dois materialismos, um fraco e um forte. $\mathrm{O}$ fraco seria a extraordinária capacidade de Antonio Candido reunir conhecimentos variados e dispersos, para sustentar a análise. $\mathrm{O}$ forte, por certo o que interessa ao modo dialético defendido por Roberto Schwarz, "busca o momento dinâmico da forma na lógica e no movimento da prática social" 39 . Nessa altura dos Pressupostos, Roberto Schwarz formula uma primeira crítica forte: na Dialética da malandragem a forma literária aparece mais estruturada que a forma histórica e social, ou seja, Antonio Candido reúne um conjunto de observações organizado pela sua afinidade com a alternância de ordem e desordem, mas não é uma totalidade $^{40}$. No passo seguinte, chega ao coração de sua crítica: a dialética da ordem e da desordem se torna uma constante cultural, o que aproxima Antonio Candido dos clássicos de Sérgio Buarque e Gilberto Freyre dos anos 30. Assim sendo, entra como problema a oscilação que complica a análise: os argumentos ora puxam em direção à história, ora em direção a um ethos cultural, "termos que não são inimigos, mas se referem a dimensões

${ }^{38}$ Ibidem, p. 139.

39 Ibidem, p. 149.

${ }^{40}$ Ibidem, p. 150. 
diferentes da realidade" ${ }^{41}$. Por extensão, essa complicada relação entre análise materialista e ethos cultural, se desdobra, fazendo da dialética da ordem e da desordem ora a experiência e perspectiva de um setor da luta de classes, ora um modo de ser brasileiro. No vértice do problema, o traço cultural desligado da vida material e do processo histórico e social efetivo pode ser generalizado, tornando-se termo de comparação, positivo, do Brasil com países mais avançados do capitalismo, como os Estados Unidos. Algo que, em circunstâncias favoráveis poderia nos ajudar, tornando vantagem uma aparente desvantagem ${ }^{42}$. Mas essa desvantagem imaginada só seria possível fazendo a passagem para o modo de ser brasileiro, deixando de lado a dinâmica do país periférico e sua posição no sistema mundial que é o próprio capitalismo. Feita a passagem do materialismo para o culturalismo, a Dialética da malandragem generaliza, operação de base da ideologia, fazendo de um modo de ser de classe um modo de ser nacional. Mas a originalidade da posição de Antonio Candido consistiria em localizar a dialética da ordem e da desordem a partir do povo comum, de um modo de ser popular, trazendo essa sociabilidade popular à frente das grandes opçóes do mundo contemporâneo ${ }^{43}$.

Ainda segundo Roberto Schwarz, na Dialética da malandragem a dimensão histórica e a dimensão folclórica se apresentam em tensão, uma amenizando a outra, o que é considerado um grande acerto. Um acerto, mas também um limite do ensaio, já que esse equilíbrio entre níveis históricos e a-históricos não será por sua vez interpretado historicamente, fazendo com que a pergunta pelo sentido de uma cunhagem folclórica do mundo moderno não seja feita, interrompendo a dialética histórica que se configurava. Interrompido o movimento dialético materialista, Antonio Candido entraria em relação mimética com a forma, tomando partido de seu sentimento de vida e atenuando a força da atualidade histórica. Por esse motivo, chega-se ao centro do problema levantado por Roberto Schwarz: a dialética da ordem e da desordem oscila entre ser contingência de uma classe ou característica nacional vantajosa, sendo o próprio mundo sem culpa ora uma "idealização feérica", ora uma "realidade social" ${ }^{44}$. Como fecho do problema, fora do círculo estetizado pela fidelidade mimética, as perspectivas sociais da Dialética da malandragem sofrem o comentário impiedoso da atualidade ${ }^{45}$.

\footnotetext{
${ }^{41}$ Idem.

${ }^{42}$ Ibidem, p. 151.

${ }^{43}$ Ibidem, p. 150-151.

${ }^{44}$ Idem.

${ }^{45}$ Ibidem, p. 152.
} 
Interrompidas as continuidades entre forma literária e processo social, Roberto Schwarz considera que Estados Unidos e Brasil, Hawthorne e Manuel Antônio, Letra escarlate e Memórias de um sargento de milícias, não são partes de histórias nacionais separadas, mas de um mundo unificado pela expansão do capitalismo, dai que "o processo social a compreender não é nacional, embora as naçóes existam" ${ }^{46}$.

Já caminhando para o final dos Pressupostos, Roberto Schwarz nota que ordem e desordem como uma polaridade histórica descomprometida remete à sociologia formalista alemã, passando uma vez mais ao largo da análise dialética materialista. Por fim, é feita a pergunta mais forte de toda a análise: não seria a própria ditadura militar brasileira um modo de oscilação entre ordem e desordem? Sem dúvida a resposta para a pergunta é afirmativa, trazendo para a linha de frente uma pesada herança brasileira, justo a das infrações contínuas das normas e estatutos legais. A ditadura militar rompeu as normas legais do país, desrespeitou o processo democrático, instalando em seguida um regime cujo vértice bárbaro foi a tortura. Abrindo caminho, graças aos grupos paramilitares do regime de exceção, ao que viria em seguida no Brasil, vale dizer, os Esquadrões da morte, parte fora da lei das polícias, e as diversas facções do crime organizado, misturadas que estavam, e continuam estando, com graus diversos de corrupção nas esferas da polícia, do judiciário, da política e, não menos importante, dos empresários que lucram com o tráfico de drogas e de armas, mas também de mercadorias roubadas. Sem esquecer que, no mesmo período, o assalto aos cofres públicos, a apropriação privada de verbas públicas, tornou-se quase que uma constante, num sistema político que, embora formalmente democrático, se acomoda a essas infrações da norma, equilibrando de modo perverso um sistema de interesses, de favores e de associações ilícitas, quase que a céu aberto.

As últimas três décadas e pouco da história do Brasil mostram, claramente, que essa violenta oscilação entre ordem e desordem pode ser mais bem entendida em termos de uma real oscilação entre civilização e barbárie, instalada no cotidiano e aterrorizando a vida cotidiana das nossas cidades, sobretudo a vida cotidiana da imensa maioria de trabalhadores, pobres e remediados, que vivem em favelas ou periferias urbanas. É a forma explícita do progresso que promove regressão, que promete fartura e felicidade e se apresenta, para usar mais uma formulação de Roberto Schwarz, como reprodução moderna do atraso. Como uma nova constelação crítica, das mais difíceis e complicadas, que pede muita reflexão, mas que não cabe no espaço desta análise.

${ }^{46}$ Ibidem, p. 153. 
Opositor firme e decidido das ditaduras, primeiro a do Estado Novo de Vargas, depois a do regime de exceção iniciado em 1964 e agravado depois de 1968, nada disso poderia ser novidade para Antonio Candido. Isso é mais do que evidente. Mas é curioso imaginar, e seguidas vezes me faço essa pergunta, por que na segunda parte da Dialética da malandragem Antonio Candido muda o rumo da análise, deixa de lado a configuração crítica por ele mesmo elaborada com tanto rigor, se deixando levar por uma crítica do capitalismo, simpática aos de baixo, aos trabalhadores, mas de base cultural, com um lastro forte de idealização. Não é difícil perceber que a posição é aparentada com certos elementos utópicos do Modernismo, mesmo em Mário de Andrade e Oswald de Andrade, assim como no ensaísmo de Sérgio Buarque e Gilberto Freyre, na década de 1930. Mas não se pode esquecer que a primeira análise das Memórias de um sargento de milícias, que se lê na Formação da literatura brasileira como romance em motocontínuo, mostra simpatia pela alegre sarabanda do livro, sem no entanto montar a figura do romance malandro, fazendo a passagem, em allegro vivace, para uma projeção otimista.

Também é curioso notar que a Dialética da malandragem foi publicada exatamente no mesmo momento de Literatura $e$ subdesenvolvimento, ensaio em que Antonio Candido critica, com rigor e clareza, variações em torno da ideologia do caráter nacional brasileiro, descartando todo tipo de exotismo, de folclorização, de cor local, de nativismo fácil e idealizado, contrapondo com firmeza a consciência amena e a consciência catastrófica do atraso. Além disso, deixando de lado as panacéias mágicas para se superar o atraso e indicando a necessidade de mudanças profundas na estrutura do país, sem as quais não se poderia avançar e, de fato, tornar memória o peso da sociedade injusta, violenta e desigual. Naquela altura, colocando o problema na esfera de uma revolução e mostrando a simpatia do autor pela revolução em Cuba.

Seguindo com a indagação, vale lembrar que, no livro $O$ discurso e a cidade, a Dialética da malandragem compõe um conjunto comparativo forte, figurando ao lado de Degradação do espaço, análise de L'assomoir, de Zola; O mundo-provérbio, que trata de I malavoglia, de Giovanni Verga; e De cortiço a cortiço, voltado para o romance de Aluísio Azevedo. Pode-se, quem sabe, argumentar que o espírito crítico de Antonio Candido valoriza sempre a variação dos pontos de vista e os ângulos das abordagens, de acordo com cada texto que é analisado. E que não seria diferente na Dialética da malandragem. É certo que parte final do ensaio, o mundo sem culpa, varia o ponto de vista crítico. Mas isso em nada refuta, ou invalida, o tipo de crítica feita por Roberto Schwarz em seus Pressupostos, como já foi exposto, em detalhe, nas páginas anteriores. E que é uma crítica rigorosa, 
vale sempre frisar, passando longe de qualquer dogmatismo de esquerda. 0 problema continua de pé. Talvez fosse o caso de imaginar que os romances de Zola, Verga e Aluísio Azevedo não deixam espaço para traços culturais se sobrepondo à vida material e suas complexas determinações, o que é verdade, mas tampouco é uma resposta convincente. Permanece a pergunta, seguindo a indagação de Roberto Schwarz: por que o país do coração deixou de lado o país real, o das classes sociais e do próprio capitalismo à brasileira, projetando traços da sociabilidade popular para além de seus limites, chegando a uma imagem positiva do país no futuro, em que uma desvantagem acaba mesmo figurando como vantagem.

Talvez seja o caso de pensar que essa projeção imaginária de traços culturais faça parte de uma tradição do Brasil moderno, que se lê em vários autores importantes, e de ângulos muito variados, apontando sempre para traços utópicos de uma possível civilização brasileira nos trópicos, que saberia tirar vantagem de sua posição periférica e atrasada, por aí se contrapondo à secura e à dureza da ética do capitalismo, como se apresenta nos países mais avançados, vale dizer, nos Estados Unidos e em certas regiões da Europa. Fico assim pensando na Antropofagia, no Matriarcado de Pindorama, no Bárbaro Tecnizado, na doce preguiça solar, na feliz miscigenação da civilização luso-tropical, no Brasil e seu povo como um amálgama poderoso de Roma com sangue negro, índio e mestiço, sem esquecer das alegorias do Tropicalismo, cujo limite, muito posterior, se encontra na idéia de uma verdade tropical, força na fraqueza, diferença cheia de qualidades. Seriam, esses traços utópicos e inconformistas, o tempo todo negados pelo rumo real que a história do país e do mundo seguiu, um grão de utopia diante das diversas pedras que havia no caminho. Mas guardam, e assim ainda o sinto e percebo, uma certa beleza, uma imaginação do possível, que não se apaga, mesmo diante da força de sucessivas e efetivas negações. Com isso não se entenda que a crítica rigorosa de Roberto Schwarz, em seus Pressupostos e no conjunto de seu trabalho, faça o papel do desmancha prazeres, cumprindo sempre a ingrata tarefa de mostrar os problemas que acompanham as idealizações - do país, de seu povo, de sua cultura. Bem ao contrário, são análises que atualizam os problemas e se apresentam como referências fortes para o debate, configurando problemas e indicando análises que, muitas delas, ainda não foram feitas.

\section{METAMORFOSES DO MALANDRO}

Não há como discordar da pergunta feita por Roberto Schwarz. A ditadura militar foi mesmo uma oscilação violenta entre ordem e desordem, norma e infração da norma, indicando um conjunto de problemas na formação 
do Brasil, quer em seu passado escravista, quer na forma moderna da sociedade urbana de classes, cuja dinâmica perversa só fez se agravar, chegando ao presente na forma de uma oscilação que se pode mesmo considerar entre civilização e barbárie. A reintegração ilegal e violenta do Brasil na esfera do capitalismo norte-americano, no contexto duro da Guerra Fria, criou as condições para os ângulos mais negativos da oscilação entre ordem e desordem, tornando coisa do passado o imaginário mais ameno associado ao malandro e à malandragem. Vale dizer, o imaginário da esperteza popular, do pobre se virando para sobreviver em posição subalterna e dependente, tentando escapar da disciplina do trabalho e da exploração que a acompanha sempre. Daí que o oposto do malandro foi sempre a figura do otário, durante muito tempo sinônimo de trabalhador assalariado, com emprego, batendo ponto, com família e horários regrados.

O imaginário da malandragem, pensado aqui a partir do Rio de Janeiro, que sempre forneceu o conjunto mais forte de referências para o assunto, era associado à vida boêmia, à música popular, ao humor e à malícia, aos pequenos trambiques e virações, mas também, o que significa bastante, à exploração de mulheres, que trabalhavam para dar a boa vida ao malandro que escapava do trabalho, e da exploração, justamente explorando essas mulheres. Fato que, por si só, já desidealiza bastante a figura, e seu modo de se dar bem escapando do batente. Mais que isso, para se dar bem o malandro não dribla apenas o patrão, mas também dá voltas nos seus iguais, em origem e posição social, marcando com isso o mundo da malandragem como competição entre os de baixo, sem nenhum horizonte de superação da injustiça social no seu conjunto. Que, aliás, nem chega a ser propriamente entendida ${ }^{47}$.

${ }^{47}$ Uma boa contribuição para o debate sobre a Dialética da malandragem foi dada por Edu Teruki Otsuka, em Era no tempo do rei: a dimensão sombria da malandragem e a atualidade das Memórias de um sargento de milícias, Tese de Doutorado defendida na FFLCH da USP, em 2005. 0 argumento crítico da tese se encontra resumido no artigo Espírito rixoso - para uma reinterpretação das Memórias de um sargento de milícias, Revista do Instituto de Estudos Brasileiros da USP, n. 44, São Paulo, fev. 2007, p. 105-124. Otsuka retoma a configuração crítica indicada por Roberto Schwarz, e a leva adiante. A malandragem, desse ângulo, não é vista como ethos cultural, nem modo de ser brasileiro, mas como parte de um espírito de rixas, de conflitos, de supremacias mais ou menos imaginárias, todas temporárias e rebaixadas, no horizonte também rebaixado do romance brasileiro em formação, por contraste com os objetivos definidos do romance realista europeu, situando assim o sistema de ações e conflitos dos personagens das Memórias no próprio espaço da sociedade escravista. Assim sendo, a malandragem se torna parte da competição limitada entre os subalternos e os que dependem do favor dos proprietários, não indo além desse horizonte restrito e negativo, o que desidealiza a malandragem e a mostra como competição sem qualquer consciência crítica organizada. Vale dizer, escravo contra escravo, pobre contra pobre, remediado contra remediado, uns contra os outros, em rixas e conflitos de pequeno alcance, circulando sempre nos limites da própria dependência e limitação histórica. 
Ainda pelo lado ameno do assunto, me vem à memória a canção que dizia mamãe eu não quero/ trabalhar de sol a sol/ quero ser cantor de rádio/jogador de futebol. Também indicando dois modos, muito recorrentes, de o pobre escapar da posição subalterna. Mas, o que se nota menos, também de fazer sua ascensão social e, quando bem sucedida a passagem, muitas vezes mudando logo de bairro, de classe, de mulher e, como se sabe, fazendo questão de exibir e ostentar todos os símbolos da riqueza adquirida com o futebol e a música popular. Processo que se tornou cada vez mais marcado, sobretudo nas últimas décadas, justamente as que começaram com a ditadura militar, e continuaram, quase em linha reta, nos diversos governos da retomada do processo eleitoral democrático no país. Cada vez mais, futebol e canção popular como mercadorias no mundo das mercadorias, por aí também se mostrando um processo de ascensão social sem crítica, de integração à ordem burguesa sem maiores problemas, talvez ficando apenas uma lição, toda baseada na competição individual e na guerra de todos contra todos: se eles se deram bem, eles que eram pobres e vieram de baixo, quem sabe eu também não possa me dar bem?

Voltando à década de 1970 , em que se deu a publicação tanto da Dialética da malandragem, de Antonio Candido, quanto dos Pressupostos, de Roberto Schwarz, vale a pena lembrar a montagem da Ópera do malandro, de Chico Buarque e Ruy Guerra, indicador muito seguro, já então, de uma metamorfose profunda na figura do malandro, que passava de simpático, boêmio, esperto mas boa gente, a arrivista sem escrúpulos, se aproveitando justamente da oscilação entre ordem e desordem trazida pela ditadura militar e da modernização autoritária do capitalismo. Porém malandro de outro tipo, regular e profissional, nunca se dando mal, agindo até nas esferas federais, bem longe dos tipos populares amenos e simpáticos do imaginário da malandragem. Registrando uma curiosa inversão, a do malandro que aposentara a navalha, trabalhava, tinha família e tralhas, mas chacoalhava no trem da Central. Vale dizer, os trabalhadores assalariados e explorados, deixados para trás por uma esperteza vinda do alto, das elites, dos dirigentes, dos poderosos montando um modelo que não se limitaria a eles, mas como que se disseminaria quase que de cima até embaixo da sociedade brasileira, modernizada, urbanizada e integrada ao modelo de consumo norte-americano.

Deixando de fato longe, mas muito longe mesmo, os arquétipos folclóricos da esperteza popular, assim como o imaginário ameno e folgado associado à vida boêmia, às criaturas da noite, à orgia, ao mundo da música popular. Inclusive, cabe acrescentar, porque nas últimas décadas a própria figura do malandro se tornou também mercadoria, uma imagem à venda, espertamente explorada pela indústria da cultura e muitíssimo lucrativa para os pobres e periféricos que se deram bem por essa via, certamente 
falsa. Por certo que uma metamorfose do malandro em mercadoria, muito visível, misturando arrivismos os mais diversos, de uma maneira indigesta e vulgar, no mundo do carnaval, samba, futebol, televisão, rádio, gravadoras, agências de propaganda e empresas privadas dos mais variados calibres, das multinacionais aos pequenos negócios de base local. Ao fundo, poderia ser ouvido o refrão, aquele que também veio da década de 1970: o negócio é se dar bem. Dito num comercial de cigarro pelo jogador de futebol famoso e talentoso. Digamos que a Lei de Gérson como um resumo, bem conciso, do processo que estava em marcha. Mas essa não era, nem poderia ser, a posição da imensa maioria dos trabalhadores brasileiros, no campo e na cidade, justamente de onde poderia vir a alternativa ao jogo pesado do capitalismo que se modernizava em ritmo acelerado. Porque os que se dão bem sempre o fazem na esfera da competição individual, na aceitação sem reservas das regras do jogo da sociedade injusta e violenta, na adesão a seco ao jogo da ascensão social e da sonhada acumulação de riqueza. Metamorfose a meu ver fundamental, que tirou de cena a figura do malandro como aquele que apenas quer escapar da disciplina do trabalho, um boêmio boa praça que não aceita a exploração e se vira nas beiradas do sistema. Daí não segue que o humor e a malícia tenham desaparecido do cotidiano e da cultura em nosso país. Mas, trazido à tona o ângulo negativo da malandragem, o humor e a malícia agora precisam ser pensados de modo crítico, cabendo sempre olhar com atenção, para distinguir as formas perversas da sociedade brasileira incorporadas à malícia e ao humor, portanto como riso que reconcilia, riso a favor do existente, riso que concorda com os dominadores e expõe ao ridículo os dominados, para lembrar aqui, de modo livre, uma posição de Theodor Adorno.

Com isso, também se desidealiza a idéia, mais para o senso comum, de que o riso e a malícia são sempre de oposição, jogam o tempo todo contra os poderosos, o que faria do humor uma arma constante dos oprimidos contra todas as formas de injustiça. Não é de jeito nenhum assim, estando esse campo volta e meia mais para uma mistura indigesta de humor, malícia, malandragem, violência, deboche e grossura, em combinações variadas, que aqui não serão analisadas. Mas também não se entenda que não haja mais humor crítico no Brasil, o que seria uma grossa redução, pois há, tanto nos espaços da vida popular, quanto no das camadas médias e altas da nossa sociedade. Às vezes, de modo involuntário e carregado de ironia, o que acrescenta uma certa graça ao conjunto.

Pelo ângulo mais difícil, de fato o mais duro de encarar, a oscilação entre ordem e desordem foi se tornando mesmo uma violenta e complicada oscilação entre civilização e barbárie. A começar com a ditadura militar, que se instalou no espaço da desordem, da ilegalidade ostensiva, da ruptura 
com as normas elementares da vida civilizada, promovendo a perseguição dos opositores, a censura e a tortura. Para reprimir a oposição de esquerda, a armada mas, vale a pena lembrar, também a desarmada, a ditadura militar criou um sistema à margem, feito de grupos paramilitares, instalações clandestinas, agindo em faixa própria e promovendo formas bárbaras de degradação. Com o apoio aberto, vale lembrar, não só de vastos setores das classes médias, mas também de empresas e grupos financeiros, nacionais e multinacionais, que não só apoiaram, mas também, em certos casos, financiaram diretamente esses grupos paramilitares agindo completamente à margem da lei.

o passo seguinte, que tem muito a ver com o primeiro, foi o surgimento dos Esquadrões da morte, organizados por policiais, além das facções do crime organizado, ligadas ao tráfico de armas e de drogas, sobretudo, mas também de mercadorias roubadas. Daí ao terror instalado no cotidiano das populações pobres e trabalhadoras, das favelas e periferias urbanas das grandes cidades brasileiras, foi um passo. Caso sirva aqui de exemplo, foi a metamorfose do malandro em bicho-solto, que se pode ler no livro Cidade de Deus, de Paulo Lins. Ou seja, do malandro boa gente, ligado à comunidade em que vivia, que agia à margem da lei mas que não aterrorizava os trabalhadores do lugar, aos bandidos da barra mais pesada, agindo de fato no espaço da própria barbárie, numa complicada associação com a corrupção instalada em vários níveis- desde o escalão mais baixo da polícia, entrando nas diversas esferas do judiciário, envolvendo políticos de diversas graduações, assim como, e não menos importante, empresários que lucram com essas atividades criminosas. Metamorfose profunda e negativa, que torna o universo das Memórias de um sargento de milícias, e aquela figura meio caricata do Major Vidigal, como que imagens amenas de um passado mais que remoto.

Na ponta mais perversa do presente, do progresso que promete fartura e felicidade mas promove regressão e violência, não há mesmo como imaginar espaços intocados na esfera da cultura popular, no campo e na cidade. Dada a força desagregadora e integrativa do processo que atende pelo nome de modernização conservadora, até mesmo o resultado violento das mudanças, a saber a própria barbárie instalada no cotidiano, se torna mercadoria, fartamente explorada em livros, em filmes, em canções, em seriados de televisão. Complicada estetização da violência, suspeitíssima sedução pela barbárie. A pretexto de "denunciar" os resultados negativos da modernização do capitalismo no país, os relatos colam na evidência do que é mais violento, encurtam a distância estética de tal modo que quase sempre não deixam espaço para qualquer posição crítica, um pouco que seja de reflexão mediada, colocando o leitor, ou o espectador, na incômoda 
posição do choque, que promove uma espécie de bloqueio cognitivo, ou pior, de adesão cega à matéria narrada. Que aparece naturalizada, uma máquina de moer que não poupa nada, nem ninguém. E que seria, por esse mesmo motivo, inevitável.

Chega a dar saudade das idealizações simpáticas, das esperanças românticas, dos populismos generosos, das compensações poéticas, dos ufanismos críticos, do país do coração às vezes andando de par com o país real, figuras que acompanharam os momentos anteriores da formação do Brasil moderno, quando havia sempre a esperança, ao menos o horizonte da superação do atraso, da criação efetiva de uma civilização nos trópicos, no limite até mesmo o horizonte de uma revolução que mudasse pra valer o país injusto, violento e profundamente enganador. Resta insistir, já que estamos postos na encruzilhada dura em que civilização e barbárie oscilam e se comunicam, em tudo que possa ser ainda civilizatório e emancipador, vale dizer, todas as ações e movimentos organizados, críticos, públicos, desde os pequenos espaços da vida cotidiana até as esferas mais gerais dos espaços públicos, onde se travam as disputas mais fortes e difíceis.

\title{
RESUMO
}

Este artigo lida com o problema posto pela crítica de Roberto Schwarz ao ensaio Dialética da malandragem, de Antonio Candido.

Palavras-chave: literatura; dialética; cultura; materialismo; Brasil; capitalismo.

\begin{abstract}
This article deals with the problem put by Roberto Schwarz's critic to the essay Dialectics of malandragem, by Antonio Candido.

Key-words: literature; dialectics; culture; materialism;Brasil; capitalism.
\end{abstract}

Submetido em: 20/03/2008.

Aceito em: 25/11/2008. 